\title{
Nutrition Tea Club; engaging students in reading scientific papers
}

\author{
Cameron, $E^{1}$., Hamdi, $\mathbf{R}^{1}$., Idowu, A $^{1}$. \& Mulrooney, H.M. ${ }^{1,2}$. \\ ${ }^{1}$ School of Life Sciences, Pharmacy \& Chemistry, Kingston University \\ ${ }^{2}$ Corresponding Author: hilda.mulrooney@kingston.ac.uk
}

Keywords: Learning environment, peer support, extracurricular, scientific reading

\begin{abstract}
Many students do not engage with reading the scientific literature, which is a core skill in undergraduate students. The learning environment has an important impact upon learning. It was postulated that taking reading out of the formal learning environment might impact upon students' willingness to engage with the literature, and confidence in doing so. A staff-student research partnership initiative funded by Kingston University allowed this hypothesis to be tested. Three Tea Club sessions, informal drop-in reading sessions were offered in a student-owned space within the Students' Union. Refreshments were supplied, aiming for a 'coffee house' feel. Although the numbers of students who engaged with the Tea Club were small, evaluations were positive. In particular students valued the opportunity for peer learning. However the chosen environment was too noisy. Future sessions will be offered within a different, less noisy environment with facilities for refreshments, and will be offered throughout the academic year to facilitate student engagement.
\end{abstract}

\section{Background}

Within the nutrition team at Kingston University (KU), we observed that many undergraduate students were not reading or engaging with the scientific literature. Study skills sessions are typically included in first year undergraduate modules, including plagiarism, citing references and academic writing skills. While all of these are important, reading and understanding the scientific literature is fundamental to developing critical analytical skills. This fear of academic reading amongst many students, and lack of awareness of how to read science papers needed to be addressed. The environment in which students learn is recognised as an important factor affecting learning (Cotterill, n.d.; Weinstein, 1979; Beard, 2009). Much undergraduate learning occurs within formalised classroom environments. However the pace of change, including technological development and use of technology by students, means that we can no longer assume that the majority of learning occurs in the classroom (Brown, 2005; Oblinger, 2006). It has been recognised that learning may be enhanced within less formal settings (Anon, 2016); for example working outside the school or classroom and flexible use of time and space have been identified as important in supporting the development of creative skills in children and young people (Davies et al, 2013).

The Nutrition Tea Club project aimed to enhance learning by offering students across all three levels of the BSc Nutrition and BSc Exercise, Nutrition \& Health degrees a relaxed environment at specific times in which to read, discuss and evaluate peer-reviewed scientific papers outside of the formal curriculum and the classroom. In the same way as reading for pleasure is typically undertaken in relaxed environments, it was hypothesised that taking the papers out of a formal academic setting would enhance 
students' willingness and ability to engage with reading scientific papers.

Students from all three years of the undergraduate programme were invited to attend on an informal drop-in basis. In addition to reading papers, the Tea Club also offered students across all three levels the opportunity to meet and mix with each other, promoting peer learning and building relationships within and between all three levels of both degrees.

The aim of this work therefore was to enhance student confidence and ability to engage with scientific literature, through peer support in relaxed voluntary extracurricular reading workshops.

\section{Methods}

Organisation: Funding to implement this scheme was successfully applied for from the Kingston University SADRAS scheme (Student Academic Development Research Associates Scheme), a staff- student initiative. The Tea Club idea was advertised to second year students studying on the BSc Nutrition or BSc Exercise, Nutrition \& Health undergraduate degree pathways. Three students applied to take part in the project as student partners (EC, Al \& $\mathrm{RH}$ ), helping to organise and run the Tea Club. A number of planning meetings were held to agree a suitable venue, times and the structure of the Tea Club (for example whether scientific papers should be supplied or students bring their own to sessions). No ethics approval was sought since the sessions were considered informal teaching sessions.

Venue: The Tea Club aimed to take scientific papers outside of the learning environment into a relaxed and informal space, ideally one 'owned' by the students. Student partners suggested the new KU Students' Union at the Penrhyn road campus as a suitable venue for the club, and booked sessions with the $\mathrm{KU}$ Students Union.

Sessions: Sessions were structured as entirely informal, drop-in sessions, each lasting two hours. A member of academic staff $(\mathrm{HM})$ was present at all sessions to monitor and oversee them, and to answer any questions that arose. It was agreed that scientific articles would be available at each session, but attendees could also bring their own. A range of scientific papers suitable for all three years of the degree programme was identified and agreed with student partners and copies were brought to each session. Each session was organised and facilitated by student partners within the Students' Union and a range of refreshments were provided, to encourage an informal 'coffee shop' feel to the sessions.

Attendees: Electronic invitations were sent to all undergraduate students on both degree pathways. Invitations were general for the first year students, but for the second and third year's invitations were linked with specific mandatory assignments (e.g. linked to required reading for a data analysis examination question for second year students, and to the papers for a 'seen' examination question for third years). The sessions were identified to all as an opportunity for peer learning but also for networking within and between levels of the degrees. Reminders were issued verbally in classes and advertised by poster in addition to the electronic invitations. Although primarily intended for Nutrition students, in practice any student could drop in and participate.

Evaluation: A baseline survey of current behaviours and attitudes toward reading scientific papers, including reading confidence was emailed to all Nutrition students on both degree pathways. This short tool used three questions; frequency of reading scientific papers, confidence in reading scientific papers and asking students to rate each of six statements (shown in Table 1) using a 5 point Likert rating scale from 1 (strongly agree) to 5 (strongly disagree).

In addition, each Tea Club was evaluated by attendees. Student partners collected baseline quantitative information on current practice and confidence in relation to reading scientific papers, using Likert ratings of selfefficacy \& attitudes after each session from 0 (not at all) to 10 (really enjoyed/used). Qualitative data related to the format and 
experience of participating in the Tea Club was also gathered.

\section{Results}

\section{Baseline data}

Baseline data relating to frequency and confidence in reading scientific papers was obtained from 13 students across all three year groups (approximately a 10\% response rate). Of these $4(31 \%)$ read papers only to find out something specific, 6 (46\%) read papers weekly, 1 (8\% rarely and $2(15 \%)$ as needed for assignments.

Confidence ratings were relatively high; with $6(46 \%)$ rating their confidence as 8 (out of a maximum of 10 ) and $3(23 \%)$ as 7 . On average the confidence rating was 6.6 with a range of 3-8. Responses to the 6 statements are shown in Table 1, expressed as numbers (\%).
There was strong recognition that reading more papers would help with studies. Respondents felt reasonably confident reading papers and knowing how to approach them; however $31 \%$ still felt they would like help in reading and understanding papers while $38.5 \%$ neither agreed nor disagreed with this statement.

\section{Tea Club sessions}

Three sessions were held, each lasting approximately 90-120 minutes. Although numbers attending were low (from 4-8 attendees), sessions evaluated well in terms of enjoyment \& utility (see Table 2 ). The rating scale used ranged from 0 (not at all) to 10 (really enjoyed/found useful). Mean ratings for confidence in reading scientific papers were lower than either enjoyment or usefulness, using the same rating scale.

\begin{tabular}{|l|c|c|c|c|c|}
\hline \multicolumn{1}{|c|}{ Comment } & $\begin{array}{c}\mathbf{1} \\
\text { (strongly } \\
\text { agree) }\end{array}$ & $\begin{array}{c}\mathbf{2} \\
\text { (agree } \\
\text { somewhat) }\end{array}$ & $\begin{array}{c}\mathbf{3} \\
\text { (neither } \\
\text { agree nor } \\
\text { disagree) }\end{array}$ & $\begin{array}{c}\mathbf{4} \\
\text { (disagree } \\
\text { somewhat) }\end{array}$ & $\begin{array}{c}\mathbf{5} \\
\text { (entirely } \\
\text { disagree) }\end{array}$ \\
\hline $\begin{array}{l}\text { I enjoy reading } \\
\text { scientific papers }\end{array}$ & $1(8 \%)$ & $\mathbf{5 ( 3 8 . 5 \% )}$ & $\mathbf{5 ( 3 8 . 5 \% )}$ & $1(8 \%)$ & $1(8 \%)$ \\
\hline $\begin{array}{l}\text { I do not feel able to } \\
\text { read scientific } \\
\text { papers }\end{array}$ & $1(8 \%)$ & $3(23 \%)$ & $0(0 \%)$ & $3(23 \%)$ & $\mathbf{6}(\mathbf{4 6 \% )})$ \\
\hline $\begin{array}{l}\text { I don't know where } \\
\text { to start when I } \\
\text { read scientific } \\
\text { papers }\end{array}$ & $1(8 \%)$ & $0(0 \%)$ & $2(15 \%)$ & $4(31 \%)$ & $\mathbf{9}(\mathbf{6 9} \%)$ \\
\hline $\begin{array}{l}\text { I feel guilty that I } \\
\text { don't read enough } \\
\text { scientific papers }\end{array}$ & $1(8 \%)$ & $\mathbf{4 ( 3 1 \% )}$ & $3(23 \%)$ & $3(23 \%)$ & $2(15 \%)$ \\
\hline $\begin{array}{l}\text { I think reading } \\
\text { more papers would } \\
\text { help my studies }\end{array}$ & $\mathbf{9 ( 6 9 \% )}$ & $\mathbf{4 ( 3 1 \% )}$ & $0(0 \%)$ & $0(0 \%)$ & $0(0 \%)$ \\
\hline $\begin{array}{l}\text { I would like help } \\
\text { reading \& } \\
\text { understanding } \\
\text { papers }\end{array}$ & $\mathbf{4 ( 3 1 \% )}$ & $2(15 \%)$ & $\mathbf{5 ( 3 8 . 5 \% )}$ & $2(15 \%)$ & $0(0 \%)$ \\
\hline
\end{tabular}

Table 1 Baseline responses to statements about attitudes to reading scientific papers $(n=13$ responses) 
Nutrition Tea Club; engaging students in reading scientific papers

\begin{tabular}{|c|c|c|c|c|}
\hline Session & $\begin{array}{c}\text { Number of } \\
\text { attendees }\end{array}$ & $\begin{array}{c}\text { How confident do } \\
\text { you feel reading } \\
\text { scientific papers? } \\
\text { Expressed as mean } \\
\text { (range) }\end{array}$ & $\begin{array}{c}\text { How much did you } \\
\text { enjoy this session? } \\
\text { Expressed as } \\
\text { mean (range) }\end{array}$ & $\begin{array}{c}\text { How useful was this } \\
\text { session for you? } \\
\text { Expressed as mean } \\
\text { (range) }\end{array}$ \\
\hline 1 & 8 & $5.5(3-8)$ & $8.75(8-10)$ & $8.75(8-10)$ \\
\hline 2 & 7 & $5.7(2-9)$ & $8.6(6-10)$ & $7.9(5-10)$ \\
\hline 3 & 4 & $6.5(6-7)$ & $6.75(6-7)$ & $7(6-8)$ \\
\hline
\end{tabular}

Table 2 Ratings of each session for confidence, enjoyment \& usefulness.

In terms of enhancing learning, all students indicated that the session(s) had enhanced their learning and all stated that they would be interested in attending future sessions.

However, in terms of specific components of the sessions that impacted upon learning, there were mixed responses. The majority of attendees in the first two sessions indicated that discussion (usually but not solely peer discussion) had strongly enhanced their understanding of the papers whereas in the final session this was not the case (see Table 3).

The environment also had a mixed impact; although the majority at each session found the environment helpful, a sizable majority ranging from 12.5 to $50 \%$ of attendees found it unhelpful.

Qualitative data was also collected: attendees were invited to comment upon the sessions, what they found helpful and what they might change. These comments shed some light, in particular with relation to the effect of the environment. Attendees liked the relaxed environment (see Table 4), but an equal number of comments related to noise (see Table 5). Students found the discussions, whether peer discussions or involving the staff member, to be really useful (see Table 4); this was the most frequent comment made relating to what was useful about the sessions.

\begin{tabular}{|c|c|c|c|c|c|}
\hline \multirow{2}{*}{ Session } & \multicolumn{3}{|c|}{$\begin{array}{c}\text { Did the discussion help you } \\
\text { understand the paper? } \\
\text { N (\%) }\end{array}$} & $\begin{array}{c}\text { Did the environment make it } \\
\text { easier to read the paper? } \\
\mathbf{N ~ ( \% )}\end{array}$ \\
\hline & $\mathbf{1}$ (a little) & $\mathbf{2}$ & $\mathbf{3}$ (a lot) & Yes & No \\
\hline 1 & $1(12.5)$ & $3(37.5)$ & $\mathbf{4 ( 5 0 )}$ & $\mathbf{7 ( 8 7 . 5 )}$ & $1(12.5)$ \\
\hline 2 & $2(29)$ & 0 & $\mathbf{5 ( 7 1 )}$ & $\mathbf{6 ( 8 6 )}$ & $1(14)$ \\
\hline 3 & $\mathbf{3 ( 7 5 )}$ & 0 & $1(25)$ & $2(50)$ & $2(50)$ \\
\hline
\end{tabular}

Table 3 Impact of the environment \& discussion upon understanding of \& ease reading scientific papers

\begin{tabular}{|l|c|}
\hline \multicolumn{1}{|c|}{ Comments } & Frequency \\
\hline Group (including staff)/peer discussions & $\mathbf{1 1}$ \\
\hline Relaxed environment & $\mathbf{4}$ \\
\hline Specific time to read papers & 2 \\
\hline Different journals available & 1 \\
\hline Found different ways of finding relevant papers & 1 \\
\hline Lecturer on hand & 1 \\
\hline
\end{tabular}

Table 4 Qualitative data on what attendees found most useful about the sessions 


\begin{tabular}{|l|c|}
\hline \multicolumn{1}{|c|}{ Possible changes } & Frequency \\
\hline Less noisy environment & 4 \\
\hline Care with distracting conversations & 1 \\
\hline
\end{tabular}

Table 5 Qualitative data on what attendees would change about future sessions

\section{Discussion}

A number of interesting observations were made relating to this pilot project. Overall the Tea Club was useful and enjoyable for participants, but in common with many cocurricular opportunities, numbers of attendees were low. Even though invitations to the second and final year students related the sessions directly to preparation for mandatory examination questions, this did not result in higher attendance. It is a truism that those who would benefit most from opportunities are often those who do not avail themselves of them, and that was certainly the case with the Tea Club. How to overcome student apathy is an ongoing problem; it may be that students do not read their emails, or were not present when the sessions were discussed in class. In that case the apathy was not solely related to co-curricular learning activities but also extended to the curriculum itself. Reading scientific papers may not be recognised as an essential skill by some students, and the timing of sessions may also have been a factor. Due to the timing of the SADRAS scheme, all the Tea Club sessions took place in the middle of the second semester when many students may have been concentrating on completing coursework or examination preparation. Whilst it could be argued that Tea Club represented an excellent opportunity for examination preparation, it was clearly not prioritised as such by students. Future Tea Club sessions will be held throughout the year including in the first semester when students may be more receptive to them.

For those who did attend, the experience was positive overall. The venue chosen had both advantages and disadvantages; it was clearly an informal student space, but conversely it was sometimes chaotic and noisy. At times the room booked was not available due to errors in the booking process, but at all times the sessions competed with other activities within the Students Union. While informal learning environments may support learning (Gerber et al, 2001), there is a balance to be struck between informality on the one hand and noise on the other. After discussions with student partners, future Tea Club sessions will be held in the Nutrition Kitchen, a small bespoke fully equipped kitchen used for Personal Tutor sessions and food science practical classes. Although this is not as informal as initially envisaged, it has refreshment facilities available and is quiet, so it may strike the appropriate balance.

The importance of peer learning was clearly identified by participants. This agrees with other research (Bearison et al, 1986; Brown et al, 1989; Webb et al, 1996). The common language shared by peers may allow them to explain concepts more easily to each other using language they all understand (Noddings, 1985), but their shared experience of life as students may also be a factor lending them mutual credibility. The presence of a staff member was also highly valued; again this agrees with other work which suggests that a major role of the teacher is to guide and facilitate learning (Lanier, 1997; McKimm \& Jollie, 2007). The relaxed and informal environment of the Tea Club allowed students the opportunity to decide their own priorities and to begin their own discussions; the staff member became involved in the conversations only if invited to do so, or to correct misinformation. Research with children has shown that those working within groups run by a leader who allowed them autonomy over their agenda were more productive than those with either authoritarian or no leadership (Marrow, 1965). In addition they 
demonstrated greater originality in their work and more independence. These are all qualities that we may aspire to facilitate in our students, but whether or not the Tea Club has a similar effect is not clear based on this limited pilot data.

Baseline evaluation showed a surprisingly confident attitude towards reading scientific papers among respondents. However only $10 \%$ of eligible students responded to the request for data so it is likely that those who responded were already reading papers and confident in their ability to do so. Again this is not an issue unique to the Tea Club; the most engaged students are also those that respond to requests for information. In future, baseline evaluation will be carried out within modules as a short in-class activity so that all those attending class will provide feedback.

In future, the intention is to continue the Tea Club, in the Nutrition Kitchen using inclass baseline evaluation to get a more accurate picture of attitudes towards, and practice in, reading scientific papers. Sessions will be offered at regular intervals, with limited refreshments (drinks only). The Personal Tutor Scheme and the KU Nutrition Society will be used as additional ways to advertise sessions. In addition, the possibility of sending specific invitations to students who would benefit most, or embedding the sessions within an existing module so that attendance is not an option, will be explored.

\section{Conclusion}

The Tea Club sessions were a useful adjunct to taught components of the course. Students who attended valued the opportunity to work specifically on papers, in an informal environment and to discuss aspects of these with each other and clarify questions with a staff member. They particularly valued opportunities for peer discussion. However uptake of the sessions was low, which in part reflects generally low uptake of co-curricular opportunities among students. It is paradoxically likely that many who did not attend would have benefitted most from the Tea Club. While an informal environment is an important part of this approach, a balance needs to be struck between a relaxed environment and one which is too noisy; the Students' Union is not the most suitable venue for future Tea Clubs.

\section{References}

Anon (2016) Informal learning settings. URL (last accessed 23/08/16): http://www.fctl.ucf.edu/TeachingAndLearni ngResources/LearningEnvironments/infor mal.php

Beard, C. (2009) Space to Learn? Learning environments in higher education. UK: Hospitality, Leisure, Sport \& Tourism Network: Enhancing series: Student Centred Learning. URL (last accessed 09/09/16):

https://www.researchgate.net/publication/2 37373418 The Enhancing Series Case Studies Student Centred Learning Spac $\mathrm{e}$ to Learn Learning Environments in $\mathrm{H}$ igher Education

Bearison, D.J., Magzamen, S. \& Filardo, E.K. (1986) Socio-cognitive conflict and cognitive growth in young children. MerrillPalmer Quarterly 32 (1), 51-72. URL (last accessed 09/09/16):

www.jstor.org/stable/23086242

Brown, A.L. \& Palincsar, A.S. (1989) Guided, cooperative learning and individual knowledge acquisition. In: Knowing, learning and instruction: Essays in honor of Robert Glaser (Resnick, L.B., Ed). Hillsdale, NJ: Erlbaum.

Brown, M.B. (2005) Learning spaces. In: Educating the Net Generation (Oblinger, D.G. \& Oblinger, J.L. eds). Washington DC: EDUCAUSE. URL (last accessed 25/08/09):

http://net.educause.edu/ir/library/pdf/pub7 101l.pdf

Cotterill, S. (n.d.) An exploration of the impact that the educational environment has on student learning. URL (last accessed 14/09/16):

http://www.winchester.ac.uk/Studyhere/Ex cellenceinLearningandTeaching/research/ ejournals/Documents/An\%20exploration\% 
20of\%20the\%20impact\%20that\%20the $\% 2$ 0educational\%20environment $\% 20$ has $\% 20$ on\%20student\%20learning.pdf

Davies, D., Jindal-Snape, D., Collier, C., Digby, R., Hay, P. \& Howe, A. (2013) Creative learning environments in education - a systematic literature review. Thinking Skills and Creativity, 8, 80-91. URL (last accessed 30/08/16): http://ac.elscdn.com/S187118711200051X/1-s2.0S187118711200051Xmain.pdf? tid=484a6072-7b78-11e6a02900000aacb35d\&acdnat $=14739669026 \mathrm{ac}$ 5dd30e701140edfc25a320f19ea35

Gerber, B.L., Cavallo, A.M.L. \& Marek, E.A. (2001) Relationships among informal learning environments, teaching procedures and scientific reasoning ability. International Journal of Science Education 23 (5), 535-549.

DOI: 10.1080/095006901750162892

Lanier, J.T. (1997) Redefining the role of the teacher: it's a multifaceted profession. URL (last accessed 23/08/16): http://www.edutopia.org/redefining-roleteacher

Marrow, A.J. (1965) The practical theorist: the life and work of Kurt Lewin. New York: Basic Books.
McKimm, J. \& Jollie, C. (2007) Facilitating learning: teaching and learning methods. URL (last accessed 23/08/16): http://www.faculty.londondeanery.ac.uk/elearning/small-groupteaching/Facilitating learning teaching learning methods.pdf

Noddings, N. (1985) Small groups as a setting for research on mathematical problem-solving. In: Teaching and Learning mathematical problem solving (Silver, E.A., Ed). Hillsdale NJ: Erlbaum.

Oblinger, D. (2006) Space as a Change Agent. In: Learning Spaces (Oblinger, D. ed). Washington DC: EDUCAUSE. URL (last accessed 15/08/16):

http://er.educause.edu/articles/2009/3/ /m edia/45e9ef07757d4db1b115d94fe2483c0 $\underline{0 . \operatorname{ash} x}$

Webb, N.M. \& Palincsar, A.S. (1996) Group processes in the classroom. In: Handbook of Educational Psychology (Berliner, D. \& Calfee, R., Eds). New York: Macmillan.

Weinstein, C.S. (1979) The Physical Environment of School: A Review of the Research. Review of Educational Research, 49 (4), 577-610. URL (last accessed 24/08/16): http://www.jstor.org/stable/1169986 